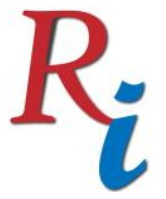

Asia Proceedings of Social Sciences

(APSS)

www.readersinsight.net/APSS

\title{
UNDERSTANDING SUPPORT FOR PARENTS OF AUTISTIC CHILDREN THROUGH A WHATSAPP GROUP \\ Rofiza Aboo Bakar*
}

Academy of Language Studies

Universiti Teknologi MARA, Cawangan Pulau Pinang

Malaysia

\section{Jazredal Aboo Bakar}

Muslim Swimming and Sports Academy

Malaysia

*Corresponding author's Email: rofiza@uitm.edu.my

Author's Biography (optional)

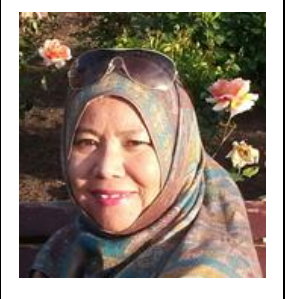

Rofiza Aboo Bakar is the Head of Department, Academy of Language Studies, Universiti Teknologi MARA, Cawangan Pulau Pinang. Her fields of interest include qualitative studies, reading, teaching of English as a second language and creativity. She has the doctoral and master's degrees in Educational Psychology conferred by the Universiti Sains Malaysia, and a degree in TESL by the University of Malaya.

Peer-review under responsibility of $3^{\text {rd }}$ Asia International Multidisciplanry Conference 2019 editorial board (http://www.utm.my/asia/our-team/) (C) 2019 Published by Readers Insight Publisher, lat 306 Savoy Residencia, Block 3 F11/1,44000 Islamabad. Pakistan,

info@ readersinsight.net This is an open access article under the CC BY-NC-ND license (http://creativecommons.org/licenses/by-nc-nd/4.0/). 


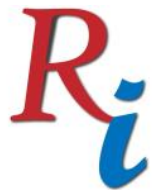

\section{Asia Proceedings of Social Sciences \\ (APSS) \\ www.readersinsight.net/APSS}

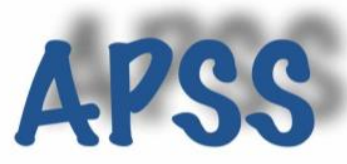

\section{Re search H i g h I igh t s}

Smartphones have allowed people to communicate actively in the $21^{\text {st }}$ century through social media. One is WhatsApp. It has provided opportunities for social groups to be in existence and consequently let ones share information and offer support. This study aimed to understand the support parents of autistic children offered to each other through a WhatsApp Group, SPARISK Support Group, that was created specifically for those who enrolled their children in a water therapy programme in Malaysia. It provided a platform for these parents to hold various discussions on caring for their autistic children. The study found that there were five types of support that parents offered among themselves: (a) types of food suitable for their children to increase concentration and combat impulsiveness; (b) relating positive behaviours of their children while undergoing the water therapy programme; (c) having the presence of professionally trained water therapy coaches; (d) informational support and (e) emotional support.

\section{Graph i c a I A bs t r a c t}

The chart below reflects the research results of this study

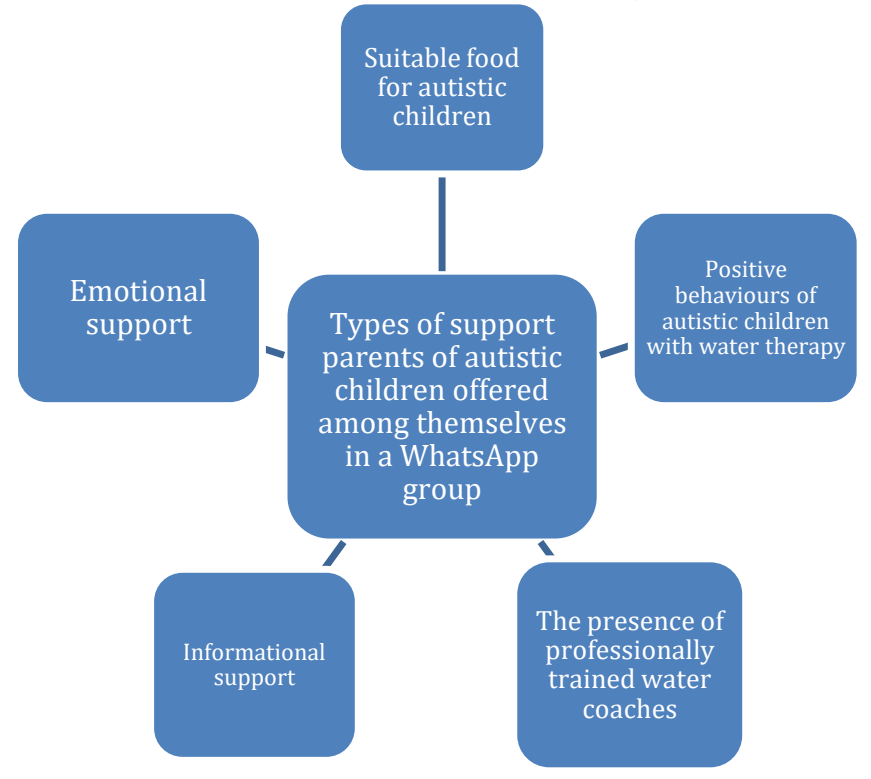

\section{Research Objectives}

Around the world, autism affects 60 in every 10000 children (Lindgren \& Doobay, 2011), with about 47000 children suffering from it in Malaysia alone (Rofiza Aboo Bakar \& Hanani Ahmad Zubir, 2018). Autistic children suffer from multifaceted deficiencies in social interaction, communication skills and physical skills (American Psychiatric Association, 2000) besides showing disruptive behaviours (Ozdemir, 2008) and having special obsessions (APA, 2000). Parents of autistic children are reported experiencing frustrations caring for them, and undergoing stress at high levels (Dabrowska \& Pisula, 2010). They need to be in touch with other parents of autistic children to allow them to share experiences and get anwers to their problems (Niela-Vilen, Axelin, Salantera, \& Melender, 2014). Therefore, connecting with each other in a support group can help them manage stress and seek for information. Since little research has been done on social media support group, particularly WhatsApp, for parents of autistic children in Malaysia, this study aimed to understand the 


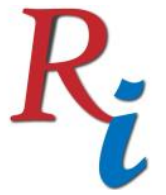

Asia Proceedings of Social Sciences

(APSS)

www.readersinsight.net/APSS

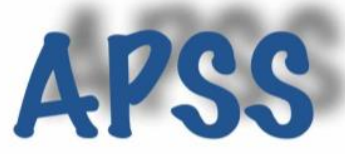

types of support they had for each other on their WhatsApp group called the SPARISK Support Group. This group came into existence as parents who enrolled their autistic children in a water therapy programme called SPARISK believed that it could benefit them in discussing various issues about their children and autism.

\section{Methodology}

In this study, a qualitative phenomenological design (Bogdan \& Biklen, 1992; Creswell, 2007) was used to understand about the support parents of autistic children enrolled in a SPARISK water therapy programe had for each other. A request letter was sent to the principal of the programme prior to the study. Four parents of different races were selected as participants and convenience sampling was used. These diversified participants were believed to provide enough data for themes and cross-case theme analysis (Creswell, 2007). The participants were a Malay male aged 50 and whose son was 14 with moderate autism, a Malay female aged 42 and whose sons were 12 and 16, with moderate and severe autism respectively, a Kadazan female aged 40 and whose son was 13 with severe autism, and a Chinese female aged 37 and whose son was 7 with moderate autism. Data were gathered using individual semi-structured interviews between 30 and 40 minutes each. The interviews were audio-recorded and transcribed, and the transcripts underwent member-checks to ensure validity and reliability. From the transcripts, identification of five important themes was reached. These themes were compared to the results obtained from similar studies to ensure accurate interpretations.

\section{Results}

This study found that there were five emerging themes:

(a) Relating types of food suitable for autistic children

Advice about food was prevalent. Parents believed that supplying fish oil and free-gluten food, and giving less sugar and dairy products would help eliminate their children's hyperactivity.

(b) Relating positive experiences with their autistic children while undergoing the water therapy programme

Parents believed that the programme had enabled their children to control their behaviours, not running away from people, exercise body balancing and utter new words.

(c) Feeling glad that they met with the professionally-trained water therapy coaches

Parents were glad that the coaches had helped their children be more focussed, and provided solutions for parents rather than harping on sad stories about autism.

(d) Informational support

Parents shared several issues like toilet-training their autistic children, finding a suitable hospital for circumcision, imparting steps to enrol children in special classes in government schools, and finding websites to teach their children reading.

(e) Emotional support

Parents shared their unique but sad experiences when they brought their children into the society. However, they believed that sad stories could not change anything. They had to find interventions to help their children have a better future.

\section{Findings}

In this study, five themes emerged from the WhatsApp support group for parents of autistic children: (a) relating types of food suitable for autistic children; (b) relating positive 


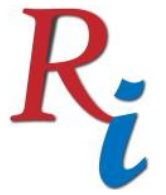

\section{Asia Proceedings of Social Sciences (APSS) \\ www.readersinsight.net/APSS}

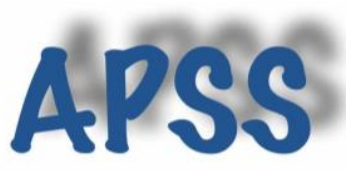

experiences with their autistic children while undergoing the water therapy programme; (c) feeling glad that they met with the professionally-trained water therapy coaches; (d) informational support; and (e) emotional support. The findings were consistent with (a) Lucarelli's et al. (1995) that autistic children's tantrums can be minimized if free-gluten food is consumed; (b) Teske's (2018) that autistic children who undergo water therapy can increase social interaction; (c, d) Cole, Kharwa, Khumalo, Reinke and Karrim's (2017) that having professionals' advice and learning from others in their support group benefit them; and (e) Hema R. Mustafa, Short and Fan's (2015) that relying on each other for emotional support is vital.

\section{Acknowledgement}

This research work is supported by Universiti Teknologi MARA, Cawangan Pulau Pinang.

\section{References}

American Psychiatric Association. (2000). Diagnostic and statistical manual of mental disorders. Washington, DC: American Psychiatric Association.

Bogdan, R. C., \& Biklen, S. K. (1992). Qualitative research for education: An introduction to theory and methods. Boston: Allyn and Bacon.

Cole, L., Kharwa, Y., Khumalo, N., Reinke, J. S., \& Karrim, S. B. S. (2017). Caregivers of school-aged children with autism: Social media as a source of support. Journal of Child and Family Studies, 26, 3464-3475. https://doi.org/10.1007/s10826-017-0855-9

Creswell, J. W. (2007). Qualitative inquiry and research design: Choosing among five approaches ( $\left.2^{\text {nd }} \mathrm{ed}.\right)$. California: Sage Publications, Inc.

Dabrowska, A., \& Pisula, E. (2010). Parenting stress and coping styles in mothers and fathers of pre-scholl children with autism and Down syndrome. Journal of Intellectual Disability Research, 54(3), 226280. https://doi.org/10.1111/j.1365-2788.2010.01258.x

Hema R. Mustafa, Short, M., \& Fan, S. (2015). Social support exchanges in Facebook social support group. Procedia - Social and Behavioral Sciences, 185, 346-351. https://doi: 10.1016/j.sbspro.2015.03.449

Lindgren, S., \& Doobay, A. (2011). Evidence-based interventions for autism spectrum disorders. The University of Iowa.

Lucarelli, S., Frediani, T., Zingoni, A. M., Ferruzi, O., Giardini, F., Quintieri, F., ... Cardi, E. (1995). Food allergy and infantile autism, Panminerva Med, 37, 137-141.

Niela-Vilen, H., Axelin, A., Salantera, S., \& Melender, H. (2014). Internet-based peer support for parents: A systematic integrative review. International Journal of Nursing Studies, 51(4), 1524-1537. https://doi.org/10.1016/j.ijnurstu.2014.06.009

Ozdemir, S. (2008). The effectiveness of social stories on decreasing disruptive behaviors of children with autis: Three case studies. Journal of Autism Developmental Disorder, 39(9), 1689-1696. https://doi: 10.1007/s10803-008-0551-0

Rofiza Aboo Bakar, \& Hanani Ahmad Zubir. (2018). Social stories: A creative way in minimizing disruptive behaviours among autistic learners. In R. A. Bakar, S. A. Rahim, \& F. N. Tazijan (Eds.), Creativity in teaching and learning: A blueprint for success (pp.9-14). Penang, Malaysia: Academy of Language Studies Publication Unit, Universiti Teknologi MARA Cawangan Pulau Pinang.

Teske, A. M. (2018). Exploring hydrotherapy with autism. Honors Research Projects, 692. 